\title{
Party Switchers and Reelection: A Precinct-Level Analysis
}

\author{
Seth C. McKee \\ Texas Tech University \\ Antoine Yoshinaka \\ University at Buffalo, SUNY \\ Keith E. Lee, Jr. \\ Georgia College \\ Richard McKenzie \\ University of South Florida
}

\begin{abstract}
We use precinct-level data to examine two questions: How does an incumbent's "reelection constituency" change following a party switch and how do those changes compare to non-switchers? Our data come from four U.S. House members who switched parties between 1995 and 2004. Among this group, one switched before the enactment of a controversial redistricting plan, and thus we assess how boundary changes and the geographic constituency interact with a change in party affiliation. We also compare each switcher's vote share with that of nonswitching incumbents running for reelection, and we show that party switchers generally do worse than their new party's co-partisans.
\end{abstract}

In American politics party switching among elected officials is an uncommon event: since 1947, twenty-four U.S. House members and nine U.S. senators switched parties. What are the systematic electoral changes that follow a party switch? The requisite electoral data to answer this question in detail has eluded political scientists for quite some time. Voter surveys typically have too few respondents residing in a party switcher's district, which hampers our ability to draw any systematic inference. Instead, scholars rely on aggregate district-level electoral data (e.g., Grose 2004; Grose and Yoshinaka 2003; Yoshinaka 2016), individual-level survey data that assess views about party switching generally (even though very few respondents are in fact represented by a switcher, e.g., Nicholson 2005), or survey data from a single state (e.g., Evans, et al. 2012; Hood and McKee 2015). A detailed look at the electoral dynamics that follow the switch is therefore lacking. Considering that a party switch can disrupt the dyadic representational linkages between representative and voter, and given that the switch often becomes a central issue in the immediate reelection campaign, gaining a better understanding of how party switchers do at the polls (both compared to their pre-switch selves and with nonswitchers) becomes an important normative and empirical question.

In this article we offer the first-ever analysis that uses data at the precinct level of geographic aggregation to determine how a party switcher's reelection constituency changes in the initial post-switch election and whether party switchers do worse than non-switchers at the ballot box. How significant is the electoral upheaval that follows the decision to switch parties? 
Despite credible empirical and theoretical models that suggest party switchers pay an electoral price, the systematic micro-level dynamics of the electoral environment still evade us. We fill this void and argue that the precinct-specific electoral context is key to understanding the postswitch electoral landscape.

In this study we examine the electoral consequences surrounding four U.S. House party switchers: Rodney Alexander (LA-5), Nathan Deal (GA-9), Ralph Hall (TX-4), and Mike Parker (MS-4). Their districts are displayed in Figure 1. These are the only four House incumbents since 1995 who faced a competitive general election both immediately prior to and following their party switch. ${ }^{1}$ It is no coincidence that these are southern Democrats who switched to the Republican Party at a time electorally favorable to the Grand Old Party (GOP). Indeed, since 1992 the Republican Party has enjoyed an ascendant and increasingly dominant position in southern congressional politics (Black and Black 2002; Hayes and McKee 2008; McKee 2010). In other words, political conditions were very promising for a handful of Democratic House incumbents to switch to the GOP in a region of the country where such a move would most likely be met with the least amount of electoral retribution.

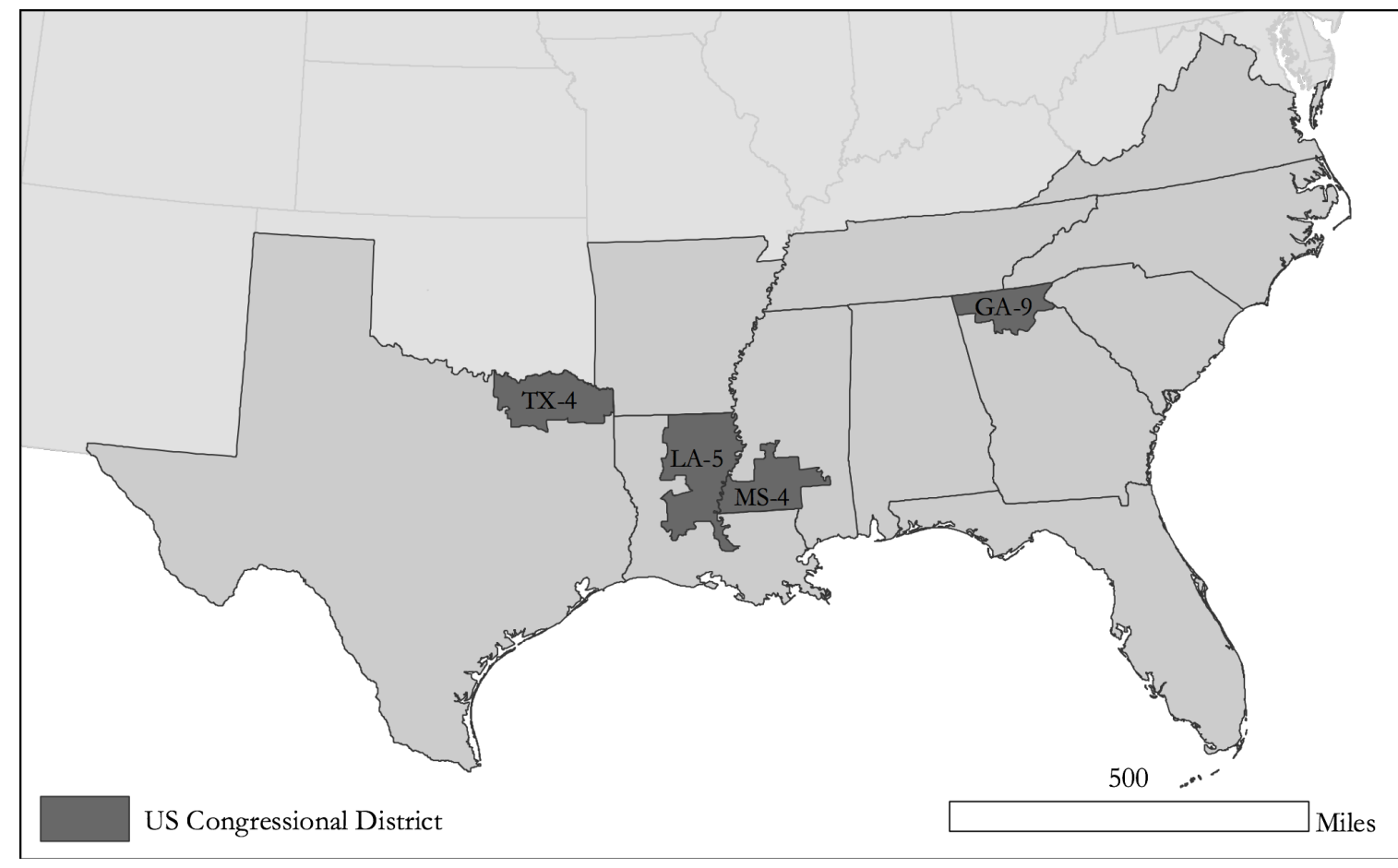

Figure 1. The Southern States and the Four Party Switchers' Congressional Districts

\footnotetext{
${ }^{1}$ We exclude Virgil Goode (VA-5) because he went from Democrat in 1998 (unopposed in the general election) to Independent in 2000 (with Democratic opposition in the general election) to Republican in 2002 (with Democratic opposition in the general election).
} 
The four cases we examine arguably provide a "hard" test from the standpoint of uncovering any negative post-switch ramifications. ${ }^{2}$ Our analyses show that party switching is followed by a marked change in the geographical distribution of an incumbent's reelection constituency, which is consistent with the possible presence of significant costs at the ballot box. We demonstrate this with precinct-level data, which goes beyond the aggregate district-level results or limited survey data from previous studies.

Although a similar historical and regional context imbues the four party switchers, there are notable differences in the political makeup of their individual districts and these differences yield considerable variation in the post-switch electoral environment. Specifically, precinct-level variation in partisanship and minority populations helps us examine the extent to which these southern Democratic incumbents' reelection constituency changes after aligning with the ascendant Republican Party.

Moreover, one of our cases (Ralph Hall) switched parties in response to the enactment of Texas's controversial 2004 "re-redistricting" (McKee and Shaw 2005). While in some ways this complicates the pre- and post-comparison of his electoral performance, we leverage this case to assess the role of incumbency in mitigating or compounding the electoral ramifications of party switching. Typically, representatives must campaign for the votes of constituents who put them in office two years prior; by switching parties they run the risk of alienating parts of that constituency who may feel "betrayed" by such a decision. However, when a new redistricting plan is implemented, party switchers face two types of constituents: one segment that elected them two years before, and another with whom they share no electoral history. We can leverage this fact to test whether the electoral dynamics differ, post-switch, in those added portions of the district. Theoretically, then, this instance of redistricting affords us the possibility of examining whether "new" voters and "old" voters differ in their post-switch electoral support.

\section{Setting the Stage for Party Switching in the South}

Fenno (1978) shows how representatives interact with constituents and what they hope to gain by cultivating a relationship with various segments of the district. Among other things, Fenno notes that members try to win the trust of constituents because with trust comes leeway, which gives them more room to exercise political independence back in Washington. In an era of dealignment of the electorate (Bartels 2000; Rosenstone and Hansen 1993), using the incumbency advantage to maximize the personal vote made political and electoral sense (see Fiorina 1977; Mayhew 1974). And despite the weaker constraining influence of political parties

\footnotetext{
${ }^{2}$ Other southern incumbents switched parties during this time period: Greg Laughlin (TX), Billy Tauzin (LA), Jimmy Hayes (LA), Virgil Goode (VA), and Parker Griffith (AL). We do not examine these cases because our criterion for inclusion was for the incumbent to have faced major-party opposition in the general election both immediately preceding and following the defection.
} 
in the 1970s, members had a working knowledge of how (and which) district residents would support their reelection.

Although Fenno never explicitly outlines a systematic profile of an incumbent's "primary constituency," even at a time when the number of strong partisans hit its nadir, we can presume that these core constituents represented the most partisan voters. To be sure, in the 1970s the personal (rather than the partisan) vote was larger and worth more to an incumbent intending to enjoy a long career in the House. And before the electorate became more politically polarized (Fenno 2000) and "sorted" (Abramowitz and Saunders 1998; Levendusky 2009), and before the "postreform House" (Rohde 1991) had ushered in an institutional environment that would eventually be known for the growing ideological distance between the parties, incumbents did indeed enjoy a much longer leash to exhibit flexibility in their roll-call voting behavior (Black and Black 2002). In short, political opportunism by members of Congress was much greater because the parties were not yet rigidly restructured along ideological lines that set litmus tests across a broad range of salient issues.

In this brief sketch of American politics in the 1970s it is apparent why there would be very little rationale for committing the ultimate act of partisan betrayal: switching political parties. And of the handful of House incumbent switches that occurred in the 1970s, all but one of the switches from one major party to the other were done by northern Republicans defecting to the majority Democratic Party - the party growing in electoral strength outside the South (Reiter and Stonecash 2011). In fact, for the entire decade of the 1970s not one sitting southern Democrat in the U.S. House switched to the Republican Party. ${ }^{3}$

Below the Potomac, the Democratic Party was the surest bet to winning elective office at any level and thus a switch to the GOP entailed more risk than reward. And of course being part of the Democratic majority in the House had its perks. Nonetheless, for a host of reasons, the most significant party realignment in U.S. history occurred in southern congressional elections, as the 1980s began a palpable and permanent shift in favor of the Republican Party. The once Solid Democratic South gave way to a dominant GOP at the presidential level in the late 1960s (Black and Black 1987) and approximately thirty years later, Republican strength was consolidated in congressional elections (Bullock, Hoffman, and Gaddie 2005).

The broader political context is vital for understanding a more general pattern of party switching in contemporary U.S. politics. By their nature most politicians are an opportunistic lot. Their voting behavior in Congress reflects the motivation to secure majority electoral support in the district (Karol 2009). The changing political environment of the American South opened up just the sort of incentives for switching parties. As time progressed forward from the highly

\footnotetext{
${ }^{3}$ Like Key (1949) we consider southern states to be the 11 states of the former Confederacy. Under alternative definitions of "the South" that include states such as Oklahoma and Kentucky (see Hayes and McKee 2008), we find one southern House member who switched parties (from Democrat to Republican) in the 1970s (John Jarman from Oklahoma).
} 
influential Reagan years, the enduring shift in favor of the Republican Party became obvious to most political observers and of course to elected southern Democrats, many of whom realized that their tenure, and in some cases progressive ambition, was more secure and attainable by switching parties.

Furthermore, a timely switch to the majority party improves the chances that a defector will secure a choice committee assignment as party leadership often bypasses the seniority system to reward party switchers (Yoshinaka 2005, 2016). It is therefore not surprising to find a number of conservative Democratic U.S. House members make the jump to the now-majority GOP during the 1990s and 2000s, four of whom are the subject of our analyses. All four party switchers were given committee assignments of equal or greater value than they had pre-switch and all were ranked based on their tenure in the House rather than their time in the Republican Party (see Yoshinaka 2016).

Although their analysis ends in 1988, which in hindsight concludes shortly before the launch of Republican ascendancy in southern U.S. House elections, Canon and Sousa (1992) document the type of ambitious behavior politicians exhibit in periods of political upheaval, characterized by the rapid rise of the minority party and the concomitant swift descent of the majority party: the success of political amateurs running under the label of the ascending party (e.g., Democrats during the New Deal period); the return of politicians of the ascending party who have been out of politics to take advantage of the favorable circumstances - aptly labeled "out of the "woodwork" candidates; and most relevant to our study, an unusually large number of politicians associated with the declining party who switch sides to join the ascending party (see Aldrich 1995 for a similar argument on the rise of the Republican Party in the 1850s).

It is this kind of behavior by politicians in the North during the New Deal that essentially repeated itself in the South in the 1990s and 2000s, where many career Democrats found it in their best interest to switch parties in order to maximize their chances of staying in their current position and perhaps someday winning a higher political office. After all, these politicians understood that the present and especially the future of southern electoral politics belonged to the GOP. But, as is true for so many endeavors, and particularly in politics, timing is critical. The window for making a successful party switch is only open for so long. In the nascent stages of a partisan realignment, switches will be viewed as more credible, especially if southern Democrats who make the switch are bona fide conservatives (as indicated by their voting records and public stances on salient issues).

\section{Theory and Hypotheses}

Past research demonstrates that the act of switching parties often comes with at least a short-term electoral cost (Grose and Yoshinaka 2003; McKee and Yoshinaka 2015; Yoshinaka 2016). More often than not, former supporters increase their efforts to unseat the legislator who 
left them for the other side. Conversely, some supporters of the representative's new party may not immediately embrace a former partisan foe. While we do not examine individual-level data that would permit us to isolate what type of voters tend to withdraw their support of party switchers (and which would-be supporters do not immediately embrace the converted legislator), we make use of the most fine-grained systematic data available to examine the geography of partisan support both prior to and following the switch, as well as the dynamics of post-switch elections relative to non-switching co-partisans. ${ }^{4}$ We assume, therefore, that party switching does create a certain amount of disruption in the legislator-constituent relationship, among both oldparty voters and new-party voters, and our analyses examine the extent to which the observed disruptions are consistent with an electoral cost story.

\section{Within-Career Hypotheses}

If the above story is correct, we should observe areas that traditionally support Democrats (Republicans) to be less (more) receptive of a former Democratic incumbent now running for reelection under the Republican label. Given the context of southern politics, we emphasize the influence of partisanship and race on the alteration of electoral vote shares for these Democrats who switch to the GOP. This leads to the following hypotheses:

Partisan hypothesis: Highly Republican areas should be more likely to support a Democratic to Republican (D-to-R) party switcher.

Race hypothesis: Areas with a high proportion of minority voters should be less likely to support a D-to-R switcher.

As we mentioned earlier, redistricting is a factor for one representative who switched parties, and we can leverage that variation to test another implication of the theory. If the theoretical story about the rupture of the representative-constituent linkage is correct, then we would expect that the "new" areas added to the district would not respond the same way as the "old" areas of the district. This dynamic is of significant interest because studies have shown that voters drawn into a new incumbent's district lack familiarity with their new representative (Hayes and McKee 2009; McKee 2008) and hence the party switch may have less electoral

\footnotetext{
${ }^{4}$ We also recognize that our analysis of four cases may not give us the inferential leverage needed to generalize to all instances of party switching (both theoretical cases of "potential" switchers and actual cases of switchers). Obviously, incumbents do not switch at random and we limit our analysis to only four instances of party switchers (and associated non-switchers). Our study, then, is akin to a series of case studies that employ the most fine-grained, aggregate electoral data available to offer the first in-depth examination of the post-switch electoral environment. We cannot fully ascertain whether the dynamics we observe were caused by the decision to switch parties, but we make the case that they are consistent with a story that emphasizes the electoral costs of that career-defining decision.
} 
relevance to their vote decision. Specifically, areas that tend to support the former party will be especially treacherous for the switcher, but perhaps less so if there was no existing relationship to break. Conversely, areas that support Republicans will be especially receptive of the party switcher if there is no history between a former Democratic legislator and his "new" constituency. This leads to the following hypotheses:

Conditional partisan hypothesis: Highly Republican areas should be more likely to support a D-to-R party switcher, and this relationship should be stronger in the "new" areas added to the district.

Conditional race hypothesis: Areas with a high proportion of minority voters should be less likely to support a D-to-R switcher, and this relationship should be stronger in the "old" areas of the district.

\section{Cross-Career Hypotheses}

Our theoretical framework, which emphasizes costs due to the former party especially keen to defeat the switcher and a new party whose supporters may not immediately embrace the switcher, also has implications for how switchers will fare relative to non-switchers. In a second set of models, we examine the electoral support of switchers to that of non-switching co-partisan Republican incumbents in the first election cycle following the switch. Such a comparison allows us to assess the extent to which a "new" Republican legislator's reelection differs from that of "old" Republican legislators.

We expect at least three dynamics pertaining to party switching. First, precincts located in a switcher's district should not be as supportive of the incumbent relative to precincts located in a non-switcher's district. Second, highly Republican areas should be less supportive of party switchers relative to Republican non-switchers (because of the "wait-and-see" period of adjustment with party switchers). Third, the "home field" advantage that incumbents receive in their home county (the "friends and neighbors" effect) should be lower for switchers. And, owing to the assumption that there will be an increase in mobilization against a party switcher, the home field advantage enjoyed by challengers should be higher for the challenger running against a party switcher than among other challengers. More formally, we hypothesize the following:

Party switching hypothesis: Voters in precincts located in a party switcher's district will be less supportive of their incumbent than voters in precincts located in a non-switcher's district (even after controlling for race and partisanship of the precinct). 
Conditional partisan hypothesis: Precincts with a large share of Republican voters should be supportive of Republican incumbents, though that correlation will be lower in precincts located in the party switchers' districts.

Conditional friends-and-neighbors hypothesis: Candidates will receive a higher vote share in precincts located in their home county. However, that bump will be lower for switchers and higher for challengers running against them.

\section{Data}

To examine the electoral aftermath of party switching we have gathered precinct/voting tabulation district (VTD)-level data on the districts where each of our four House incumbents sought reelection after joining the GOP. In geographic terms, precincts and VTDs are essentially equivalent units of population aggregation, constituting the smallest political building blocks making up a district. Technically, a "precinct" refers to a single polling location assigned to a geographically defined number of eligible voters, but in the vast majority of cases VTDs are treated the same way and for our analytical purposes these units are equivalent. We reiterate that this is the first time that such fine-grained electoral data have been used to study the electoral ramifications of party switching.

We have comparable data on the four party switchers, with the most important objective being the collection of precinct-level information on election returns, partisanship, race, and redistricting. In addition to the obvious need for U.S. House returns on our party switchers, we have gathered presidential election returns in order to provide a baseline for partisanship. We have managed to secure precinct-level racial data based on African-American registration in Georgia, according to voting age population (VAP) in Mississippi and Texas, and based on registration and turnout in Louisiana. Because Ralph Hall ran for reelection under significantly altered district boundaries, we provide an indicator for precincts redrawn into his district prior to the 2004 election. Finally, because of the electoral significance of political localism, often referred to as the "friends-and-neighbors" effect (see Key 1949; Meredith 2013), we denote precincts located in the switcher's home county (or parish) as well as those located in the home county of their opponent(s).

Table 1 provides summary information on the data we have collected to assess the electoral implications for these four party switchers. As shown, all four party switchers sought reelection as Republicans in presidential years and we have precinct-level election returns for president in 1996 and 2004. These data provide a proxy measure for precinct-level partisanship with the expectation that our switchers, ceteris paribus, perform better in more Republican precincts. For our party switchers we have racial data at the precinct level. This consists of the percent registered African Americans in Georgia, registration and turnout by race in Louisiana 
(percent white, black, and other) and the percent voting age population for Anglos (AVAP), blacks (BVAP), Hispanics (HVAP), and others (OVAP) in Mississippi and Texas.

Table 1. Precinct-Level Data Collected on Party Switchers

\begin{tabular}{|c|c|c|c|c|}
\hline $\begin{array}{l}\text { Incumbent and } \\
\text { Elections }\end{array}$ & Partisanship & Race & Redistricting & Home County \\
\hline $\begin{array}{l}\text { Rodney Alexander } \\
(2002-04)\end{array}$ & $\begin{array}{l}2004 \text { Presidential } \\
\text { returns }\end{array}$ & $\begin{array}{l}\text { Registration/Turnout: } \\
\text { Black, White, Other }\end{array}$ & None & $1=\mathrm{Jackson}$ Parish \\
\hline $\begin{array}{l}\text { Nathan Deal } \\
(1994-96)\end{array}$ & $\begin{array}{l}1996 \text { Presidential } \\
\text { returns }\end{array}$ & Black Registration & Yes, but minimal & $1=$ Hall County \\
\hline $\begin{array}{l}\text { Ralph Hall } \\
(2002-04)\end{array}$ & $\begin{array}{l}2004 \text { Presidential } \\
\text { returns }\end{array}$ & $\begin{array}{l}\text { AVAP, BVAP, HVAP, } \\
\text { OVAP }\end{array}$ & 1 = Redrawn VTDs & $1=$ Rockwall County \\
\hline $\begin{array}{l}\text { Mike Parker } \\
(1994-96)\end{array}$ & $\begin{array}{l}1996 \text { Presidential } \\
\text { returns }\end{array}$ & $\begin{array}{l}\text { AVAP, BVAP, HVAP, } \\
\text { OVAP }\end{array}$ & None & $1=$ Lincoln County \\
\hline
\end{tabular}

NOTE: AVAP = Anglo voting age population; BVAP = black voting age population; HVAP $=$ Hispanic voting age population; and OVAP = other voting age population. The Mississippi racial data also include American Indian VAP and Asian VAP but given the small numbers we have collapsed them into the OVAP category. Louisiana has voter registration according to party affiliation and race, with race separated into white, black, and other categories. Further, the Louisiana Secretary of State records turnout by precinct according to race and we use both types of data in our analyses. The Louisiana data were compiled from the online files made available by the Louisiana Secretary of State's elections and voting website: www.sos.la.gov/ElectionsAndVoting/GetElectionInformation/Pages/default.aspx. The 1994 VTD election returns for Georgia were made available by Brian Fraher of the National Committee for an Effective Congress (NCEC) and the 1996 Georgia VTD election returns were procured from the old Georgia Reapportionment Services Office several years ago when these data were archived online through a website operated through the University of Georgia's Carl Vinson Institute of Government (redistricting services are now provided through the Georgia Republican Party). Because our analysis of the 1996 Georgia redistricting reveals such a minimal impact on District 9 (we can only account for a single redrawn VTD in Cherokee County), it does not factor into the statistical model of electoral support for switcher Nathan Deal. All of the VTD-level data for Texas were made available through the Texas Legislative Council. The Mississippi data were compiled from three different sources. Ben Collins, the GIS Operations Coordinator for the Mississippi Legislature provided us with shapefiles that included precinct-level racial data. Most of our precinct-level Mississippi election returns were collected online from the Mississippi Department of Archives and History (MDAH): mdah.state.ms.us/arrec/digital_archives/series/lublin/. Professors David Lublin (American University) and D. Stephen Voss (University of Kentucky) digitally deposited these election returns data into the MDAH. Because the MDAH data are not complete, with the absence of election return records for several counties, we have supplemented them with precinct-level election returns provided by the NCEC. Despite our best efforts, because of inconsistences across these various data sources our precinct-level data for Mississippi are not 100 percent complete.

\section{Descriptive Spatial Analysis}

Before turning to our multivariate statistical analyses, we examine changes in each party switcher's district in pre- and post-switch settings. Given the considerable variation in racial composition across the four incumbents' districts, coupled with the reality of data limitations, the descriptive spatial analysis presented here caters to the most pronounced features of these districts. First, we have precinct shapefiles, but in some cases the data are not complete for both pre- and post-switch election years. For Nathan Deal's $9^{\text {th }}$ District the data are $97 \%$ complete and 
90\% complete for Mike Parker's $4^{\text {th }}$ District in Mississippi. We have complete precinct/VTD data in spatial form for Texas District 4 and Louisiana District 5.
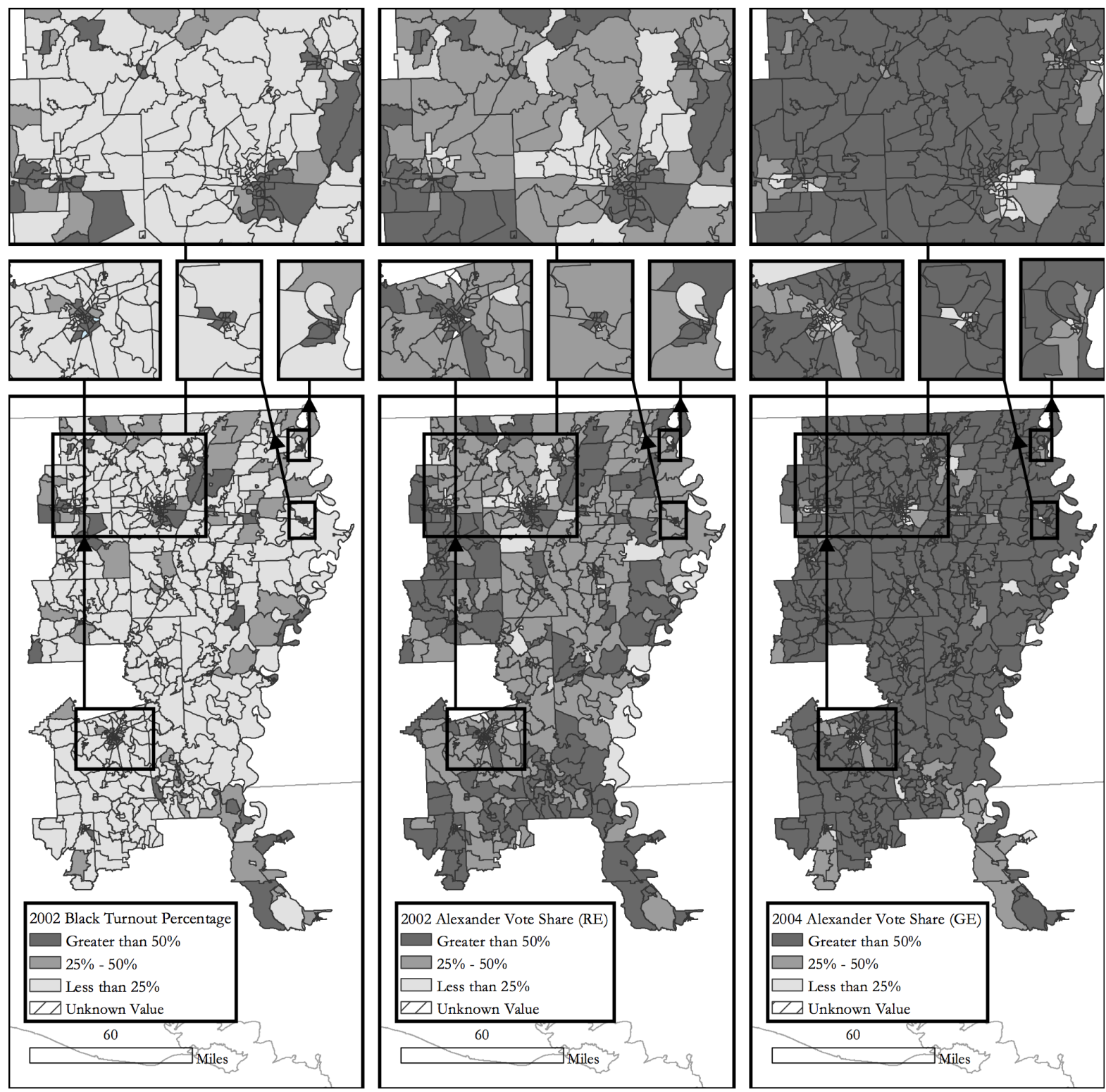

Figure 2. Racial Demographics and Election Results in Congressman Rodney Alexander's District in 2002 and 2004

There are very high percentages of African Americans in Louisiana's $5^{\text {th }}$ District (34\%) and Mississippi's $4^{\text {th }}$ District (41\%). In the case of Mike Parker (MS-4), this would be the highest district percentage of African Americans to be represented by a white Republican in the entire country and Rodney Alexander's district is not far behind. Therefore, the most telling feature of these districts located comfortably in the Deep South are their very high black populations. 
Because African Americans are the most staunchly Democratic voters, areas where they are concentrated are expected to show the greatest amount of inter-election variation. ${ }^{5}$
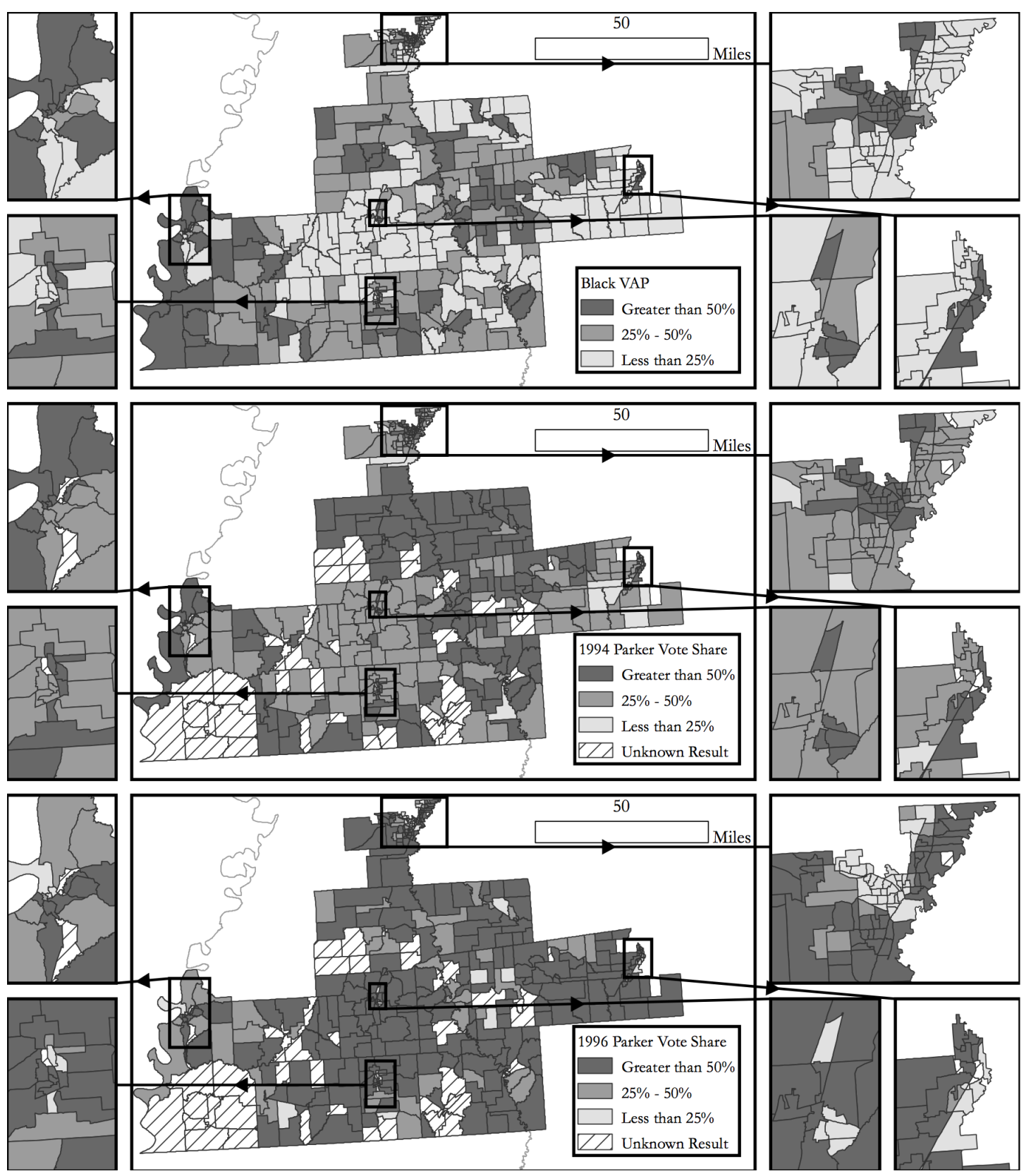

Figure 3. Racial Demographics and Election Results in Congressman Mike Parker's District in 1994 and 1996

\footnotetext{
${ }^{5}$ Because we lack individual-level data, we cannot make strong conclusions regarding the behavior of individual voters or even groups of voters. Yet we argue that geographically we should observe these patterns given the extent to which bloc voting occurs. Also, we argue that these inter-election vote swings are consistent with our theory, if not necessarily demonstrating it directly.
} 
The spatial presentations (displayed in Figures 2 and 3) therefore highlight the vote allocated to Alexander and Parker in the pre- and post-switch elections as juxtaposed next to maps that indicate the black composition of their precincts' electorate. In all of the figures displayed in this section (Figures 2-5), we employ map shading that distinguishes among three ranges for a given variable: less than $25 \%$, between 25 and $50 \%$, and over $50 \%$. A close inspection of these figures shows how Alexander and Parker do very well in majority black precincts when they run as Democrats and then these same precincts overwhelmingly turn against them when they switch to the Republican Party.
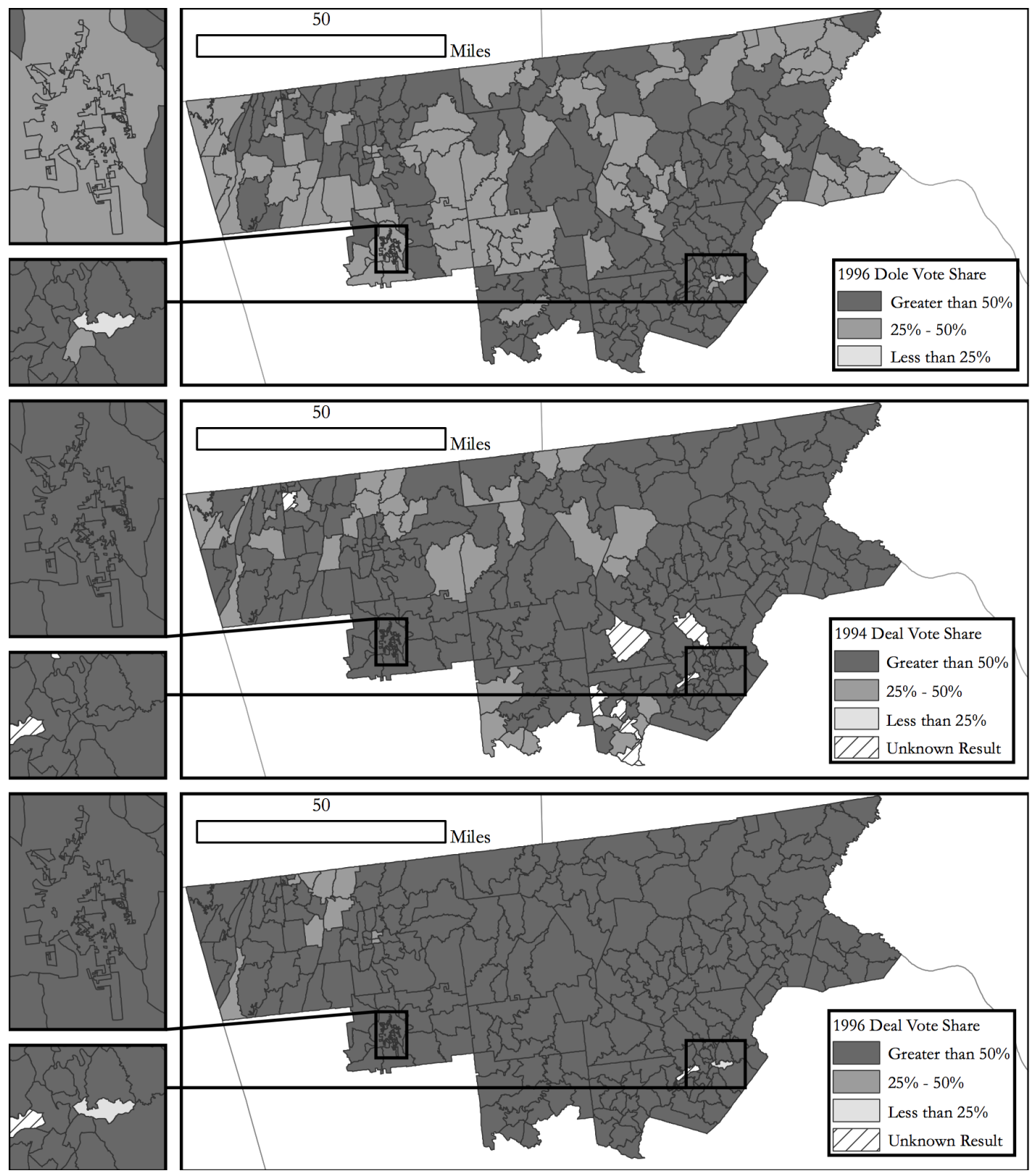

Figure 4. The 1996 Republican Presidential Vote and House Election Results in Congressman Nathan Deal's District in 1994 and 1996 
Since the minority populations are very small in Congressman Deal's north Georgia district, Figure 4 instead displays the district's 1996 Republican presidential vote and how it compares against the congressional vote for Deal in 1994 (pre-switch) and 1996 (post-switch). It is remarkable how evident Deal's vote share improved in 1996, after switching to the GOPoutperforming Dole's impressive presidential returns - and almost blanketing the district with precincts casting a majority Republican House vote for the erstwhile Democrat. ${ }^{6}$

Given the low minority percentages in Ralph Hall's Texas district and redistricting's overriding importance, the descriptive spatial analysis for this incumbent (Figure 5) displays vote shares pre-switch (the district as configured in 2002) and post-switch (the redrawn district in 2004) with a clear delineation between parts of the 2004 district consisting of retained precincts and redrawn precincts. The 2002 district (on the left) is a narrower shape that juts its way from the Oklahoma border to the southeast. By contrast, the 2004 manifestation (on the right) is more compact and shifts upward and eastward, with the northern border comprising the Red River (the Oklahoma/Texas and Arkansas/Texas state lines). It is clear from Figure 5 that Hall's switch made political sense since the bulk of his new precincts picked up through the 2004 redistricting cast majority Republican House votes. Notable exceptions to this pattern exist in several of the precincts located in the eastern portion of the district (registering majority Democratic House votes).
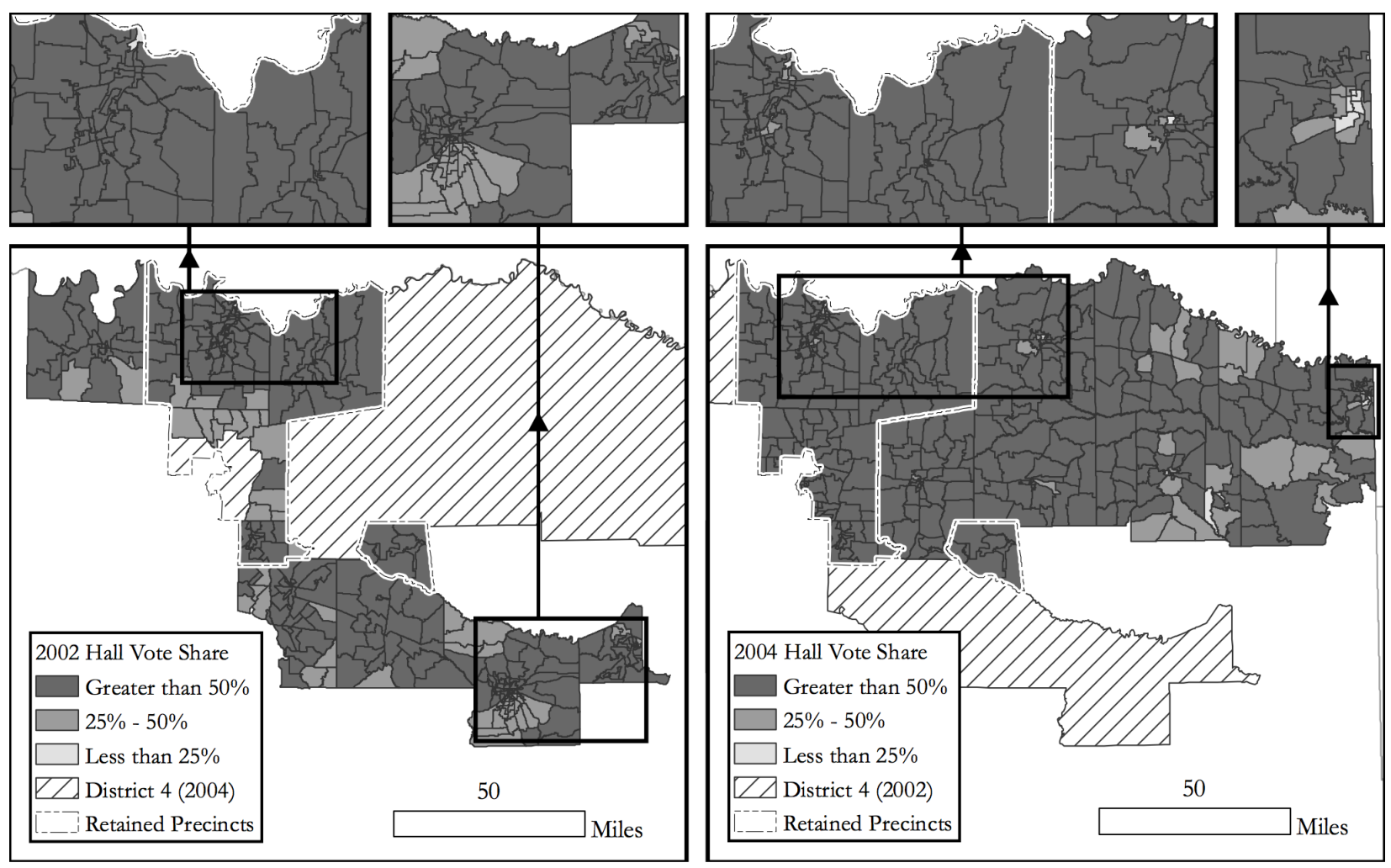

Figure 5. Election Results in Congressman Ralph Hall's District as Configured in 2002 and 2004 


\section{Statistical Results}

While the preceding geographical descriptions are instructive, they do not allow us to make inferences in a multivariate setting, which we turn to in a regression framework. In our first set of analyses, the dependent variable is each party switcher's change in the two-party vote from the election immediately preceding the switch to the contest that immediately followed it. We measure the change at the level of the precinct/VTD, which gives us several hundred observations for each party switcher. We analyze each party-switching incumbent separately via an OLS regression. We eschew the estimation of a pooled model because some of the variables (e.g., the various race measures) simply cannot be compared across our cases. In addition, the significant redistricting of Ralph Hall's congressional district in 2004 is a unique feature of that case, which we of course leverage in order to gauge the extent to which the post-switch environment differs in those areas where the incumbent-voter relationship is nascent.

In the analyses that follow, we are unable to assess the effects of party switching for Rodney Alexander. What complicates matters considerably is that Alexander's district contained 746 precincts in 2002 and the number jumps to 850 for the 2004 election despite no redistricting. Further complicating matters is that so many of the precincts in 2002 and 2004 have the same name even though the geographic territory of the precinct may have changed and it is not clear which precincts were altered to create the 2004 version of a precinct whose name remains the same from 2002. Since the models in this section compare the difference in an incumbent's vote share in a given precinct/VTD pre- and post-switch, there are too many precincts where we are unable to make a one-to-one spatial match to conduct such an analysis.

The second and third columns of Table 2 show the results of our regression model for Nathan Deal's precincts. We exclude 26 out of 242 precincts - one because they were redrawn into Deal's district in 1996, another because they were split between several districts, and there were two-dozen precincts whose boundaries shifted between 1994 and 1996. ${ }^{7}$ On the right-hand side we include variables measuring the precinct's proportion of black registered voters, Bob Dole's and Ross Perot's share of the vote in the 1996 presidential election, and dummy variables for three counties: Hall, Lumpkin, and Catoosa counties, where Nathan Deal, Robert Castello (Deal's Republican opponent in 1994), and Ken Poston (Deal's Democratic opponent in 1996) resided, respectively. Model 2 also includes Deal's vote share in 1994 (the lagged vote) in order to account for the fact that this variable is bounded at 0 and 1 , which means that we would expect all else equal a higher vote share in 1994 to diminish in 1996, and a smaller 1994 vote share to increase in 1996.

\footnotetext{
${ }^{7}$ An issue we ran into is that some precinct boundaries changed between 1994 and 1996. While many of these changes were quite small, we still include most of these precincts in our model (excluding precincts whose boundaries shifted considerably). To alleviate concerns that we are introducing significant measurement error into our data, we also estimated a separate model on precincts whose boundaries remained intact. Results from that analysis were substantively and statistically similar to those we present here (results available on request).
} 
Table 2. Regression Analyses of Party Switchers' Electoral Support, Pre- versus Post-Switch

\begin{tabular}{|c|c|c|c|c|c|c|c|c|}
\hline $\begin{array}{l}\text { Nathan Deal } \\
\text { (GA-9) }\end{array}$ & $\begin{array}{l}\text { Model } 1 \\
\text { B (s.e.) }\end{array}$ & $\begin{array}{l}\text { Model } 2 \\
\text { B (s.e.) }\end{array}$ & $\begin{array}{l}\text { Mike Parker } \\
\text { (MS-4) }\end{array}$ & $\begin{array}{l}\text { Model } 3 \\
\text { B (s.e.) }\end{array}$ & $\begin{array}{l}\text { Model } 4 \\
\text { B (s.e.) }\end{array}$ & $\begin{array}{l}\text { Ralph Hall } \\
\text { (TX-4) }\end{array}$ & $\begin{array}{l}\text { Model } 5 \\
\text { B (s.e.) }\end{array}$ & $\begin{array}{l}\text { Model } 6 \\
\text { B (s.e.) }\end{array}$ \\
\hline $\begin{array}{l}\text { Black voter } \\
\text { registration }\end{array}$ & $-.02(.10)$ & $-.13(.06)^{* * *}$ & Black VAP & $-.21(.07)^{* * * *}$ & $-.07(.02)^{* * * *}$ & Black VAP & $-.36(.10)^{* * * *}$ & $-1.28(.36)^{* * * *}$ \\
\hline $\begin{array}{l}\text { Dole } \\
\text { presidential } \\
\text { vote }\end{array}$ & $1.31(.09)^{* * * *}$ & $.71(.06)^{* * * *}$ & $\begin{array}{l}\text { Hispanic } \\
\text { VAP }\end{array}$ & $3.54(2.08)^{*}$ & $-.47(.68)$ & Hispanic VAP & $.12(.11)$ & $.33(.24)$ \\
\hline $\begin{array}{l}\text { Perot } \\
\text { presidential } \\
\text { vote }\end{array}$ & $.67(.20)^{* * * *}$ & $.32(.12)^{* * * *}$ & Other VAP & $.73(1.50)$ & $-.37(.49)$ & Other VAP & $2.95(.38)^{* * * *}$ & $-1.35(1.11)$ \\
\hline Hall County & $-.12(.02)^{* * * *}$ & $.01(.01)$ & $\begin{array}{l}\text { Dole } \\
\text { presidential } \\
\text { vote }\end{array}$ & $1.36(.08)^{* * * *}$ & $.88(.03)^{* * * *}$ & $\begin{array}{l}\text { Bush } \\
\text { presidential } \\
\text { vote }\end{array}$ & $1.27(.09)^{* * * *}$ & $.74(.13)^{* * * *}$ \\
\hline $\begin{array}{l}\text { Lumpkin } \\
\text { County }\end{array}$ & $-.00(.02)$ & $-.02(.01)$ & $\begin{array}{l}\text { Perot } \\
\text { presidential } \\
\text { vote }\end{array}$ & $1.22(.29)^{* * *}$ & $1.08(.09)^{* * * *}$ & Redrawn VTD & --- & $-.73(.13)^{* * *}$ \\
\hline $\begin{array}{l}\text { Catoosa } \\
\text { County }\end{array}$ & $-.12(.03)^{* * * *}$ & $-.16(.02)^{* * * *}$ & $\begin{array}{l}\text { Lincoln } \\
\text { County }\end{array}$ & $.09(.03)^{* * * *}$ & $-.01(.01)$ & $\begin{array}{l}\text { BVAPx } \\
\text { Redrawn VTD }\end{array}$ & --- & $1.19(.38)^{* * * *}$ \\
\hline $\begin{array}{l}\text { House Dem } \\
\text { vote ' } 94\end{array}$ & --- & $-.92(.05)^{* * *}$ & $\begin{array}{l}\text { Jones } \\
\text { County }\end{array}$ & $.13(.03)^{* * * *}$ & $-.02(.01)^{*}$ & $\begin{array}{l}\text { HVAP } x \\
\text { Redrawn VTD }\end{array}$ & --- & $-.13(.27)$ \\
\hline \multirow[t]{5}{*}{ Constant } & $-.68(.07)^{* * * *}$ & $.20(.06)^{* * * *}$ & $\begin{array}{l}\text { Hinds } \\
\text { County }\end{array}$ & $.05(.02)^{* * *}$ & $-.05(.01)^{* * *}$ & $\begin{array}{l}\text { OVAP } \times \text { Redra } \\
\text { wn VTD }\end{array}$ & --- & $4.67(1.17)^{* * * *}$ \\
\hline & & & $\begin{array}{l}\text { House Dem } \\
\text { vote ' } 94\end{array}$ & --- & $-1.07(.02)^{* * *}$ & $\begin{array}{l}\text { Bush } \\
\text { vote } \times \text { Redrawn } \\
\text { VTD }\end{array}$ & --- & $.89(.17)^{* * *}$ \\
\hline & & & Constant & $-.58(.07)^{* * * *}$ & $.23(.03)^{* * * *}$ & $\begin{array}{l}\text { Rockwall } \\
\text { County }\end{array}$ & $-.01(.04)$ & $.11(.04)^{* * *}$ \\
\hline & & & & & & Camp County & $-.14(.09)$ & $-.15(.08)^{*}$ \\
\hline & & & & & & Constant & $-.84(.07)^{* * *}$ & $-.38(.09)^{* * *}$ \\
\hline $\mathrm{N}$ & 216 & 216 & $\mathrm{~N}$ & 367 & 367 & $\mathrm{~N}$ & 360 & 360 \\
\hline Adjusted $R^{2}$ & .68 & .89 & Adjusted $R^{2}$ & .90 & .99 & Adjusted $R^{2}$ & .66 & .72 \\
\hline $\begin{array}{l}\text { Std. error of } \\
\text { regression }\end{array}$ & .08 & .05 & $\begin{array}{l}\text { Std. error of } \\
\text { regression }\end{array}$ & .14 & .04 & $\begin{array}{l}\text { Std. error of } \\
\text { regression }\end{array}$ & .17 & .16 \\
\hline
\end{tabular}

NOTE: The dependent variable in each respective model is: the difference between Nathan Deal's vote share in 1994 and 1996 (positive values indicate an increase from 1994 to 1996); the difference between Mike Parker's vote share in 1994 and 1996 (positive values indicate an increase from 1994 to 1996); the difference between Ralph Hall's vote share in 2002 and 2004 (positive values indicate an increase from 2002 to 2004).

${ }^{* * * *} p<0.01 ;{ }^{* *} p<0.05 ;{ }^{*} p<0.10$ (two-tailed)

Model 1 shows that Deal did better in 1996 relative to 1994 in precincts where Bob Dole did well. The Republican presidential vote is by far the best predictor of the change in Nathan Deal's House vote. He also did better than two years prior in precincts where Ross Perot did well, though the relationship is not as strong as with the Dole vote. ${ }^{8}$ Looking at the county

\footnotetext{
${ }^{8}$ The difference between the two coefficients is quite large and statistically significant (difference $=0.64, p<0.001$ ).
} 
dummies, we see that Deal did significantly worse in Catoosa County, which was the county of residence of his 1996 opponent Ken Poston. This is indicative of a friends-and-neighbors vote that rewarded the local candidate. Two results are somewhat surprising (though, as we show in Model 2, can be accounted for with Deal's lagged vote): the insignificant coefficient for black registration and the negative and statistically significant coefficient for Hall County. With respect to the former, we must remember that Georgia's Ninth District was racially very homogenous. The vast majority of precincts were under $2 \%$ black, with only a few precincts with a high proportion of black registrants. The black vote is, simply stated, not much of a concern in this district. With respect to the negative coefficient for Hall County, it suggests that in his county of residence Nathan Deal did worse in 1996 relative to 1994 compared to other counties.

However, this last result is simply a function of the fact that Nathan Deal did exceptionally well in Hall County in 1994 (winning that county by about 10 percentage points more than he won the district). The results from Model 2 show that once we control for Deal's vote in 1994, the coefficient for Hall County is no longer distinguishable from zero. On the other hand, the coefficient for black registration is now negative and statistically significant, as expected. And while the size of the coefficients for the Dole and Perot presidential vote are now smaller, they are still positive and highly significant (and statistically different from each other). Finally, as expected, the coefficient for Deal's vote share in 1994 is negative and statistically significant. This simply indicates that a positive change is much more difficult to obtain in a precinct where he received a large share of the vote in 1994, and conversely a positive change is much easier to achieve in precincts where his 1994 vote total was low. Our results are consistent with the expectation that Deal did significantly better in "redder" areas in 1996 relative to his performance in 1994 in those same areas.

Next, we present the regression models estimated on the precincts/VTDs of Mike Parker's $4^{\text {th }}$ District in Mississippi. As with the Georgia data, there are some discrepancies in precinct boundaries between 1994 and 1996. We exclude about 15\% of precincts for which we could not reliably match the 1994 and 1996 data. Model 3 shows that precincts with a high proportion of black voting age population significantly withdrew their support of Parker in 1996. As stated earlier, Parker's district was more than $40 \%$ black so the importance of race cannot be overstated. For each additional 5 percentage points in black VAP, Parker's vote share was expected to be lowered by about 1 percentage point in 1996 relative to 1994. On the other hand, the coefficient for Hispanic VAP is positive and significant; however, with a district that was less than $1 \%$ Hispanic, this result means very little substantively in terms of the shift in vote shares from 1994 to 1996. Similar to the results for Nathan Deal, we find a positive correlation between the Dole vote and the Perot vote, on the one hand, and the change in Parker's support from 1994 to 1996, on the other. We also find that Parker did better in the counties of Lincoln (his home county), Jones (his 1994 opponent's home county), and Hinds (his 1996 opponent's home 
county). Though, as was the case with Deal, these findings are contingent on whether we control for our incumbent's House vote in 1994.

In Model 4 we control for Parker's vote in 1994. Again, the coefficients for black VAP, the vote share for Dole, and the vote share for Perot are statistically significant and in the expected direction. Their magnitude is lower than in Model 1, which should not surprise us since Deal's vote in 1994 was certainly correlated with race and the underlying partisanship of each precinct. We now find, however, that precincts located in Lincoln County (Parker's home county) were no more or less likely to support their local candidate than precincts in other counties. Also, Parker did significantly worse in precincts located in Hinds County, which was the home county of his 1996 opponent, Kevin Antoine. Parker also did marginally worse in Jones County, which was the home county of his 1994 Republican opponent Mike Wood. Finally, the negative and significant coefficient for Parker's 1994 vote is consistent with the fact that he was unlikely to increase his support in areas where he already did well. The results from both Parker's and Deal's analyses are generally consistent with each other, and they both demonstrate that a party switcher's reelection constituency is dramatically altered by the switch.

Finally, in the last two columns of Table 2 we look at the regression estimates for Ralph Hall. The Texas data have two distinct advantages over the other cases. First, the VTD boundaries do not change from 2002 to 2004, so we can measure the exact change in Hall's vote in every part of his district. Second, due to redistricting, Hall's district gained new territory in 2004. This gives us leverage to examine how the switch interacts with the addition of this new territory. If, as we surmise, the costs of switching are mostly felt in the "old" parts of the district, we would expect Hall to do quite well in the new parts of his district. In those parts, we compare Hall's 2004 vote as a Republican to the Democratic vote in 2002, most of which were cast for Democratic Congressman Max Sandlin in the $1^{\text {st }}$ congressional district. ${ }^{9}$

In Model 5 we estimate a regression on all 360 VTDs that does not take into account the fact that a significant number of VTDs were redrawn. The main result is that areas with a larger black population were more likely to withhold their support for the Democrat-turned-Republican incumbent. Also, there is a strong positive relationship between a VTD's support for George W. Bush in 2004 and the change in House vote for Ralph Hall. And Hall did worse in Camp County, the home county of Hall's 2004 opponent, Democrat Jim Nickerson $(p<0.12)$.

In Model 6 we take account of the fact that some VTDs were redrawn into Hall's district and we interact that with the race and partisanship variables. What is interesting is that while the lower-order term for BVAP is still negative and statistically significant, the interaction term of $\mathrm{BVAP} \times$ Redrawn is positive, statistically significant, and nearly of identical size as the lower-

\footnotetext{
${ }^{9}$ The $4^{\text {th }}$ District contains 360 VTDs, 247 of which were added to the district in 2004. Of those new VTDs, 211 came from the "old" $1^{\text {st }}$ District represented by Democrat Max Sandlin. The remaining came from the "old" $3^{\text {rd }}$ District (31 VTDs represented by Republican Sam Johnson) and the "old" $26^{\text {th }}$ District (5 VTDs represented by Republican Michael Burgess).
} 
order term. This shows that in those redrawn portions of the district, the size of the BVAP of a VTD bears no relationship to how well Hall did in 2004 relative to how well the Democrat did in 2002. This result holds even if we exclude the small number of VTDs from "old" districts represented by Republicans, thus comparing only Hall's VTDs to the VTDs that were in the "old" $1^{\text {st }}$ District represented by Democrat Max Sandlin. What this suggests is that the "backlash" against the switch may have been felt more strongly among "bluer" areas that were part of Hall's old geographic constituency. In the new portions of the district, the size of the BVAP has no impact (because the sum of BVAP and BVAP $\times$ Redrawn is essentially zero). In the "old" parts of the district, on the other hand, the size of the black population is negatively correlated with Hall's vote. While the BVAP of the average VTD is about $10 \%$, about 1 out of every 10 VTDs has a BVAP of more than $25 \%$, so this result is substantively significant as well.

Another interesting finding pertains to the effect of the underlying partisanship captured by the two-party presidential vote. In the "old" parts of the district, the lower-order term for partisanship shows that there is a positive and statistically significant effect on Hall's vote. In addition, the interaction between that variable and the redrawn dummy variable shows that the effect is significantly stronger in redrawn areas. It appears that in those areas, voters may be using party as a proxy at a higher rate. Without the incumbency advantage, Ralph Hall must rely mostly on his party affiliation to attract voters. This also suggests that highly Republican areas may be somewhat less likely to immediately embrace a newly converted Republican when that area had a relationship with that incumbent. Constituents in newly added territory, on the other hand, did not have the opportunity to vote for/against Hall when he was a Democrat. Another way to think of these results is that the deleterious effect of adding new constituents may be mitigated if those new areas have a party skew benefiting the incumbent. Also, the "friends-andneighbors" vote is alive and well: Hall did much better in his home county (Rockwall) and much worse in the home county of his 2004 opponent (Camp County).

While these results pertaining to redistricting do not offer a causal estimate of any sort, they are indicative of potential electoral costs that manifest themselves according to our theoretical assumptions. With little to no history of a constituent-representative relationship, the act of switching parties may be perceived very differently by voters that are new to the incumbent. In the case of supporters of the former party (in this case, African Americans), the results certainly indicate the possibility that it is voters in the "old" district who are especially eager to unseat a now-Republican incumbent. And in the case of supporters of the new party (in this case, Republicans), our results are consistent with the assumption that there is a "wait-andsee" period of adjustment that translates into a much stronger "party" effect in the "new" parts of the district. Again, we must recognize that our data are measured at the aggregate level (even though each unit of aggregation is quite small) and not at the individual level. So our results 
should be taken as being consistent with our theoretical story, though by no means an ironclad test of its empirical implications.

\section{Comparing Republican Switchers to other Republican Incumbents}

How do party switchers fare relative to non-switchers? This is a thorny question that surprisingly few scholars have attempted to answer (though see Yoshinaka 2016). Yet it is a critical element of our story regarding the post-switch environment. Specifically, how do switchers fare compared to loyal co-partisans? To answer this question, we compare each of the four Republican switchers to every Republican incumbent who ran for reelection in the first postswitch election in the same state as each switcher. Our unit of analysis is every VTD/precinct in the first election year following a switch. So, for instance, we compare Nathan Deal's precinctlevel results in 1996 with those of the other seven Republican incumbents who sought reelection that year in the state of Georgia. In addition to a dummy variable for party switchers, we include each precinct's Republican presidential vote share (and the Perot vote in 1996), racial composition (either the voting age population or registered voters depending on data availability), dummy variables for the home county (or parish in the case of Louisiana) of each incumbent and challenger, dummies specific to the switcher's and his opponent's home county (or two opponents in the case of Louisiana's all-party ballot), and campaign spending. ${ }^{10}$ In the Texas case, we also include income (which we could only gather for VTDs in the Lone Star State), the presence of a Democratic incumbent on the ballot (since redistricting pitted some incumbents against each other in 2004), as well as the redistricting dummy variable denoting whether the VTD was added to the incumbent's district since the previous election. ${ }^{11}$

The dependent variable is the Republican two-party House vote in the first post-switch election year. We estimate two models in each case: an additive model and a multiplicative model where we interact the switcher dummy variable with the Republican presidential vote and, in the Texas case, with the redrawn VTD dummy variable. If party switching is costly, we expect it to manifest itself in at least two ways. First, owing to the potential backlash to a switch, we expect that a switcher's home county advantage will not be as strong as that of a non-switcher. Similarly, we expect the bump enjoyed by the challenger to be higher in the case of a switcher's opponent. This is due to the theoretical expectation that a switcher will cause increased

\footnotetext{
10 We omit spending data for Louisiana and Mississippi since in those states only one other Republican incumbent sought reelection, which creates perfect collinearity between spending and the switcher dummy variable.

${ }^{11}$ We do not explicitly model the non-random nature of the decision to switch parties, which of course precludes us from making causal claims about the effect of party switching. We are therefore testing for the presence of relationships that, if not causal, are at least consistent with our theoretical claims about party switching costs. Also, it is important to remember that prior to switching parties, eventual congressional switchers do not have lower vote shares than non-switchers (see Yoshinaka 2016). While we do not account for the confounding factors that lead some precincts to be represented by a party switcher while others are represented by non-switchers, we are at least confident that eventual switchers did not, prior to the switch, have lower vote shares than non-switchers.
} 
Table 3. Regression Analysis of the House Vote for Republican Switchers versus Other Republican Incumbents

\begin{tabular}{|c|c|c|c|c|c|c|c|c|}
\hline \multirow[b]{2}{*}{$\begin{array}{l}\text { Independent } \\
\text { variable }\end{array}$} & \multicolumn{2}{|c|}{ GA GOP incumbents } & \multicolumn{2}{|c|}{ LA GOP incumbents } & \multicolumn{2}{|c|}{ MS GOP incumbents } & \multicolumn{2}{|c|}{ TX GOP incumbents } \\
\hline & $\begin{array}{l}\text { Model } 1 \\
\text { B (s.e.) }\end{array}$ & $\begin{array}{l}\text { Model } 2 \\
\text { B (s.e.) }\end{array}$ & $\begin{array}{l}\text { Model } 3 \\
\text { B (s.e.) }\end{array}$ & $\begin{array}{l}\text { Model } 4 \\
\text { B (s.e.) }\end{array}$ & $\begin{array}{l}\text { Model } 5 \\
\text { B (s.e.) }\end{array}$ & $\begin{array}{l}\text { Model } 6 \\
\text { B (s.e.) }\end{array}$ & $\begin{array}{l}\text { Model } 7 \\
\text { B (s.e.) }\end{array}$ & $\begin{array}{l}\text { Model } 8 \\
\text { B (s.e.) }\end{array}$ \\
\hline Switcher VTD & $-0.06(0.01)^{* * *}$ & $-0.01(0.02)$ & $-0.12(0.01)^{* * *}$ & $-0.09(0.01)^{* * *}$ & $0.01(0.01)$ & $0.01(0.01)$ & $-0.02(0.00)^{* * *}$ & $-0.03(0.02)^{* *}$ \\
\hline Redrawn VTD & $-0.04(0.00)^{* * *}$ & $-0.04(0.00)^{* * *}$ & --- & --- & --- & --- & $-0.04(0.00)^{* * *}$ & $-0.04(0.00)^{* * *}$ \\
\hline $\begin{array}{l}\text { Switcher VTD } \\
\times \\
\text { Redrawn VTD }\end{array}$ & --- & -- & -- & --- & -- & -- & -- & $-0.01(0.01)$ \\
\hline GOP pres. vote & $0.83(0.02)^{* * *}$ & $0.84(0.02)^{* * *}$ & $0.80(0.02)^{* * *}$ & $0.84(0.03)^{* * *}$ & $0.86(0.02)^{* * *}$ & $0.87(0.02)^{* * *}$ & $0.95(0.01)^{* * *}$ & $0.94(0.01)^{* * *}$ \\
\hline $\begin{array}{l}\text { Switcher VTD } \\
\times \\
\text { GOP pres. Vote }\end{array}$ & --- & $-0.10(0.04)^{* *}$ & --- & $-0.06(0.01)^{* * *}$ & --- & $-0.01(0.02)$ & --- & $0.03(0.02)$ \\
\hline Perot vote & $0.43(0.05)^{* * *}$ & $0.43(0.05)^{* * *}$ & --- & --- & $0.93(0.06)^{* * *}$ & $0.93(0.06)^{* * *}$ & --- & --- \\
\hline $\begin{array}{l}\text { Black VAP/ } \\
\text { reg. }\end{array}$ & $-0.05(0.02)^{* * *}$ & $-0.04(0.02)^{* * *}$ & $0.03(0.02)^{*}$ & $0.04(0.02)^{* *}$ & $-0.14(0.02)^{* * *}$ & $-0.14(0.02)^{* * *}$ & $-0.05(0.01)^{* * *}$ & $-0.04(0.01)^{* * *}$ \\
\hline $\begin{array}{l}\text { Hispanic VAP/ } \\
\text { reg. }\end{array}$ & --- & -- & --- & --- & $0.17(0.46)$ & $0.18(0.46)$ & $0.06(0.01)^{* * *}$ & $0.06(0.01)^{* * *}$ \\
\hline Other VAP/reg & --- & --- & $-0.03(0.08)$ & $-0.05(0.08)$ & $-0.48(0.35)$ & $-0.47(0.35)$ & $0.06(0.02)^{* * *}$ & $0.06(0.02)^{* * *}$ \\
\hline $\begin{array}{l}\text { Household } \\
\text { income }\end{array}$ & --- & -- & --- & -- & -- & --- & $-0.00(0.00)^{* * *}$ & $-0.00(0.00)^{*}$ \\
\hline $\begin{array}{l}\text { Inc. home } \\
\text { county }\end{array}$ & $0.02(0.00)^{* * *}$ & $0.02(0.00)^{* * *}$ & $0.08(0.02)^{* * *}$ & $0.08(0.02)^{* * *}$ & $0.03(0.01)^{* * *}$ & $0.03(0.01)^{* * *}$ & $0.06(0.00)^{* * *}$ & $0.06(0.00)^{* * *}$ \\
\hline $\begin{array}{l}\text { Chall. home } \\
\text { county }\end{array}$ & $-0.06(0.00)^{* * *}$ & $-0.06(0.00)^{* * *}$ & $-0.09(0.02)^{* * *}$ & $-0.08(0.02)^{* * *}$ & $-0.02(0.01)^{*}$ & $-0.02(0.01)^{*}$ & $0.01(0.00)^{* * *}$ & $0.01(0.00)^{* * *}$ \\
\hline $\begin{array}{l}\text { Switcher's } \\
\text { county }\end{array}$ & $-0.00(0.01)$ & $0.00(0.01)$ & $-0.02(0.02)$ & $-0.02(0.02)$ & $-0.03(0.01)^{* *}$ & $-0.03(0.01)^{* *}$ & $-0.02(0.01)^{*}$ & $-0.03(0.01)^{* *}$ \\
\hline $\begin{array}{l}\text { Non-switcher's } \\
\text { county }\end{array}$ & $-0.10(0.02)^{* * *}$ & $-0.10(0.02)^{* * *}$ & $-0.03(0.01)^{* * *}$ & $-0.03(0.01)^{* * *}$ & $-0.03(0.01)^{*}$ & $-0.03(0.01)^{* *}$ & $-0.18(0.03)^{* * *}$ & $-0.17(0.03)^{* * *}$ \\
\hline $\begin{array}{l}2^{\text {nd }} \text { non- } \\
\text { switcher's } \\
\text { county (LA } \\
\text { only) }\end{array}$ & --- & -- & $-0.14(0.01) * * *$ & $-0.13(0.01)^{* * *}$ & --- & --- & --- & --- \\
\hline $\begin{array}{l}\text { Dem. } \\
\text { incumbent }\end{array}$ & --- & -- & --- & --- & --- & --- & $-0.30(0.01)^{* * *}$ & $-0.30(0.01)^{* * *}$ \\
\hline $\begin{array}{l}\text { Dem. spending } \\
\text { (in } \$ 000 \text { ) }\end{array}$ & $0.00(0.00)^{* * *}$ & $0.00(0.00)^{* * *}$ & --- & --- & --- & --- & $0.00(0.00)^{* * *}$ & $0.00(0.00)^{* * *}$ \\
\hline $\begin{array}{l}\text { GOP spending } \\
\text { (in } \${ }^{\prime} 000 \text { ) }\end{array}$ & $-0.00(0.00)^{* * *}$ & $-0.00(0.00)^{* * *}$ & --- & --- & -- & --- & $-0.00(0.00)^{* * *}$ & $-0.00(0.00)^{* * *}$ \\
\hline Constant & $0.28(0.02)^{* * *}$ & $0.27(0.02)^{* * *}$ & $0.24(0.02)^{* * *}$ & $0.21(0.02)^{* * *}$ & $0.22(0.01)^{* * *}$ & $0.22(0.02)^{* * *}$ & $0.14(0.01)^{* * *}$ & $0.14(0.01)^{* * *}$ \\
\hline $\mathrm{N}$ & 1939 & 1939 & 1338 & 1338 & 776 & 776 & 3609 & 3609 \\
\hline Adjusted $\mathrm{R}^{2}$ & 0.88 & 0.88 & 0.92 & 0.92 & 0.94 & 0.94 & 0.92 & 0.92 \\
\hline $\begin{array}{l}\text { Std. error of } \\
\text { the } \\
\text { regression }\end{array}$ & 0.05 & 0.05 & 0.06 & 0.06 & 0.05 & 0.05 & 0.06 & 0.05 \\
\hline
\end{tabular}

NOTE: The dependent variable is the two-party House Republican vote in districts where the GOP incumbent is seeking reelection in the first post-switch election.

*** $p<0.01 ;{ }^{* *} p<0.05 ;{ }^{*} p<0.10$ (two-tailed) 
mobilization and a concerted effort from the opposing party and candidate. Finally, we expect the Republican vote to be lower in precincts located in a switcher's district even after controlling for the various factors that correlate with the House vote. And, if the theoretical story about the new party not immediately embracing the switcher is correct, we expect switchers to do especially poorly in precincts dominated by the supporters of the new party. This is what the interaction between the switching dummy and a precinct's Republican presidential vote can assess. ${ }^{12}$ Table 3 shows the results of a series of OLS regression analyses. ${ }^{13}$

Starting with the model estimated on Georgia Republican incumbents, we find in Model 1 that the Republican vote was significantly lower in Nathan Deal's precincts than in the precincts located in other GOP incumbents' districts, to the tune of about six percentage points. The negative coefficient for the interaction in Model 2 shows that this difference is especially pronounced in highly Republican precincts. This shows that Nathan Deal did much worse, relative to other Republican incumbents, in highly Republican precincts. What this suggests is that there may be some hesitation on the part of many Republicans to embrace a newly converted party switcher. In Deal's case, perhaps some Republican voters were wary of supporting an incumbent whose voting record as a Democrat had not always been impeccably pro-life (Barone and Ujifusa 1997). It certainly suggests that Deal had more difficulty amassing large majorities in Republican precincts than the other seven Republican incumbents running for reelection in 1996.

Also in line with the theoretical story that emphasizes party-switching costs, we find that Nathan Deal did much worse in his opponent's home county than other Republicans generally did in their opponent's home county. The difference is about 10 percentage points and it is highly significant. This result is consistent with the theoretical expectation that switchers will face stiff opposition in their first post-switch election, and that this opposition often comes with a significant mobilization effort by the switcher's opponent. This is likely to be felt strongly in the challenger's own home county, and the results in the Georgia case support this hypothesis.

Looking at the Louisiana case, our results are largely consistent with our theoretical expectations. Like Nathan Deal, Rodney Alexander fared significantly worse than the other

\footnotetext{
${ }^{12}$ Our models do not include the lagged incumbent vote. While it certainly makes sense to control for the support each incumbent received in the previous election, for three of the four states in the analyses, there were too many differences in precinct boundaries between elections to reliably control for that factor. We were able to do so painstakingly for just the switchers' districts earlier (though we still had to exclude Louisiana from the switchersonly analyses). We note, however, that in the one state in which the boundaries remained intact (TX), our results do not change in any significant way if we include an incumbent's vote share in 2002 (results available on request).

${ }^{13}$ On theoretical grounds, we would expect the error term for all the precincts located in a given district to be correlated with each other, but to be independent from precincts located in other districts. This situation can be remedied by estimating standard errors clustered on the district. However, we encounter the problem that the number of clusters in each analysis is worryingly small (between 2 and 13). Given that clustered standard errors have asymptotic properties requiring a large number of clusters, we opt to report results with non-clustered standard errors. However, the results from analyses with clustered standard errors show that the size of the clustered standard errors and associated $t$-ratios are very similar to those we report here (results available on request).
} 
Republican incumbent running in 2004 (Richard Baker in District 6). In Model 3 we see that his vote percentage was about 12 points lower than Baker's (controlling for underlying partisanship, race, and home parish, which explain a very large proportion of the variance in the Republican House vote). In Model 4 we see that this effect was even higher in highly Republican precincts. Just like Nathan Deal, it appears that voters in highly Republican precincts were less likely to embrace the new Republican incumbent relative to a non-switching Republican incumbent. Moreover, we find that Alexander's opponents received a higher home-parish bump than did Baker's opponents. Just as was the case with Deal, then, our results suggest that there was a counter-mobilization to the switch, which is evidenced by the larger home-parish bump enjoyed by the switcher's opponent.

Moving on to Mississippi, we find that Mike Parker's two-party vote share at the precinct level was not significantly worse than Roger Wicker's in District $1 .{ }^{14}$ However, the results pertaining to the home counties of incumbents and challengers are entirely consistent with the theoretical story of switchers not immediately embraced by their new potential supporters while facing increased opposition from their old party. Indeed, while Roger Wicker enjoyed a threepoint bump in his home county, Mike Parker did not have a significant advantage in his home county (since the positive coefficient for incumbent home county and the negative coefficient for the switcher's home county cancel each other out). Furthermore, while Wicker's opponent enjoyed a 2-point bump in his home county, Parker's opponent's home county advantage was 3 percentage points bigger for a total of a five-point bump.

Turning to the Texas analysis, Model 7 shows that the Republican vote was 2 percentage points lower in VTDs in Hall's district than in VTDs located in districts represented by other Republican incumbents. While a Republican incumbent gets an additional 6 percentage points in VTDs located in his/her home county, in the case of Ralph Hall, the "home court" advantage is only about 4 percentage points (or 3.4 to be exact, since rounding to the second decimal the coefficients are 0.057 and -0.023 , respectively, for all GOP incumbents' and Ralph Hall's home county). What this suggests is that some of Hall's core constituents may be withholding their support somewhat after the switch relative to the core constituents of non-switching GOP incumbents. And district-wide, his support was slightly lower than the support for a typical Republican incumbent, holding constant other aspects of their constituencies.

In Model 8, we include an interaction between Hall VTDs, on the one hand, and VTDs that were redrawn into the district and the Republican presidential vote, on the other. The insignificant coefficient for the interaction with redistricting shows that Hall did not do any

\footnotetext{
${ }^{14}$ While we are a bit hesitant to make too much out of this one result, one possible explanation for this lack of "retribution" in the Parker case is that his district was viewed as the most racially polarized in the nation (see Lublin 2004). In such a polarized setting, it is likely that white Republican voters would have one goal in mind, that is to return Mike Parker to Congress against the first-ever black Democratic candidate to win his party's nomination in that district. Race, in other words, trumped everything else, including any possible concerns with a party-switching incumbent.
} 
worse, relative to other Republican incumbents, in those areas that were added to his district. The lower-order term for redrawn areas (-0.04) shows that on average, Republican incumbents' vote totals are about 4 percentage points lower in those redrawn areas compared to areas that they kept from 2002. But that effect is not any different for Ralph Hall. And while the interaction between Hall and the presidential vote is not significant $(p<0.15)$, its point estimate is still important when estimating the difference between Hall and other Republican incumbents. The marginal effect of Hall's VTDs over the entire range of the presidential vote variable ranges from $-3.1 \%$ to $-0.1 \%$; for realistic values (e.g., $10^{\text {th }}$ and $90^{\text {th }}$ percentiles), the marginal effect ranges from $-1.6 \%$ to $-0.7 \%$.

Taken together, the results of these analyses show that Hall did worse than other Republican incumbents, even after controlling for such important factors as campaign spending, presidential vote, and race and ethnicity. Those variables already explain a lot of the variation in the Republican House vote. Yet, we find that the House Republican vote was lower, on average, in Hall's district than in other districts held by Republican incumbents seeking reelection. This suggests that perhaps there is a cost to switching parties, even if it is small, that is statistically significant. Hall was a "success story," being reelected five times since his switch (though he finally lost in 2014 in the Republican primary). His is therefore a "hard case" from the standpoint of finding significant electoral costs. Nonetheless, we show that Hall did slightly worse than expected for a Republican incumbent with his profile. He also received a smaller home county bump than what other incumbents typically enjoy, which again is consistent with a slight home electoral cost story.

\section{Conclusion}

In this study we provide the first-ever systematic analysis of the changes in the reelection constituency of legislative party switchers, and we do so with data gathered at a much more finegrained level (i.e., the precinct/VTD) than what other scholars have done. We therefore provide an important step in the quest to understand how the relationship between representatives and constituents changes following a legislator's decision to switch parties. With the precinct as the unit of analysis we uncover systematic relationships between a switcher's vote share and essential features of House districts, mainly measures of partisanship, racial composition, and the influence of redistricting.

Our examination focused on four southern Democrats who switched to the GOP between 1995 and 2004, when Republicans took control and subsequently solidified their dominance of House elections in this region of the United States. Further, because our four switchers had twoparty opposition immediately before and after their switch, we are able to assess how partisanship, race, and for one incumbent, redistricting, influence support for party defectors. Through geographical and statistical analyses, it is clear that, despite the fact that only one 
incumbent received a lower percentage of the vote post-switch, there are significant electoral costs to switching parties. Specifically, two of our incumbents did markedly worse among heavily black precincts in their districts located in Deep South states, and our incumbent whose district was greatly altered by redistricting performed considerably worse in the parts of the district that were added. Of course, party switchers were able to offset these costs with increased vote shares in highly Republican precincts. In hindsight, aligning with the ascending party was a smart move for all of these party switchers.

Finally, we go beyond a pre/post comparison for each of the four incumbents and assess how they fared against fellow non-switching Republican incumbents running for reelection (with major party opposition) in their state delegation. This analysis, particularly where we have more than one comparison case (in Georgia and Texas), makes it evident that versus non-switching Republicans, our party switchers perform significantly worse in their initial post-switch reelection bid, especially in highly Republican areas. While we cannot be certain that this effect is causal, it does raise the possibility that certain segments of the new party may not immediately embrace a switcher. Also, our results are consistent with the idea, put forth in Yoshinaka (2016), that the former party will be especially motivated to unseat their erstwhile co-partisan representative.

Our findings indicate that a party switch has clear representational consequences. As Fenno (1978) reminds us, representatives do not have the same relationship with every segment of their district. They view those who vote for them very differently from those who do not. As a result, it is likely that the representational linkages between constituents and their representatives change dramatically after a switch. Normatively, this raises more questions than it answers. How representatives and constituents negotiate these changes would make for a theoretically insightful study with significant implications. If, as we suspect, these changes are short-lived, perhaps the few instances of party switching offer a glimmer of hope that voters and elites may be more flexible in their partisan attachments than what is often depicted by those who continuously sound the alarm that the country is incurably polarized along partisan and ideological lines. The fact that after an initial reluctance, many are willing to embrace a former foe suggests that voters may have a short memory - and this may ultimately be good for politics in America.

We presented previous versions of this paper (with the title: "Who Punishes Party Switchers?") at the annual meetings of the American Political Science Association, Washington, D.C., August 2014; the Midwest Political Science Association, Chicago, IL, April 2014; and the biennial meeting of the Citadel Symposium on Southern Politics, Charleston, SC, March 2014. We benefited from the helpful suggestions of our discussants Jennifer Wolak, Shannon Jenkins, and Dave Rohde, and our anonymous reviewers. Finally, we thank Pam Lopez for providing valuable research assistance. 


\section{References}

Abramowitz, Alan I., and Kyle L. Saunders. 1998. "Ideological Realignment in the American Electorate." Journal of Politics 60: 634-652.

Aldrich, John H. 1995. Why Parties? The Origin and Transformation of Political Parties in America. Chicago: University of Chicago Press.

Barone, Michael, and Grant Ujifusa. 1997. The Almanac of American Politics 1998. Washington, D.C.: National Journal.

Bartels, Larry M. 2000. "Partisanship and Voting Behavior, 1952-1996." American Journal of Political Science 44(1): 35-50.

Black, Earl, and Merle Black. 1987. Politics and Society in the South. Cambridge: Harvard University Press.

Black, Earl, and Merle Black. 2002. The Rise of Southern Republicans. Cambridge: Harvard University Press.

Bullock, Charles S. III, Donna R. Hoffman, and Ronald Keith Gaddie. 2005. "The Consolidation of the White Southern Congressional Vote.” Political Research Quarterly 58(2): 231-243.

Canon, David T., and David J. Sousa. 1992. "Party System Change and Political Career Structures in the U. S. Congress.” Legislative Studies Quarterly 17(3): 347-363.

Evans, Kevin, Rolfe Peterson, and Nathan Hadley. 2012. "Principled or Opportunist? Perceptions of Arlen Specter and His Party Switch During the 2010 Midterm Election." American Politics Research 40(5): 880-902.

Fenno, Richard F. 1978. Home Style: House Members in their Districts. Boston: Little, Brown, and Co.

Fenno, Richard F. 2000. Congress at the Grassroots: Representational Change in the South, 1970-1998. Chapel Hill: University of North Carolina Press.

Fiorina, Morris P. 1977. Congress: Keystone of the Washington Establishment. New Haven: Yale University Press.

Grose, Christian R. 2004. "Is It Better to Join the Majority? The Electoral Effects of Party Switching by Incumbent Southern State Legislators." American Review of Politics 25: 79-98.

Grose, Christian R., and Antoine Yoshinaka. 2003. "The Electoral Consequences of Party Switching by Incumbent Members of Congress, 1947-2000.” Legislative Studies Quarterly 28(1): 55-75.

Hayes, Danny, and Seth C. McKee. 2008. “Toward A One-Party South?” American Politics Research 36(1): 3-32.

Hayes, Danny, and Seth C. McKee. 2009. "The Participatory Effects of Redistricting." American Journal of Political Science 53(4): 1006-1023.

Hood, M. V. III, and Seth C. McKee. 2015. "Sunshine State Dilemma: Voting for the 2014 Governor of Florida." Electoral Studies 40: 293-299.

Karol, David. 2009. Party Position Change in American Politics: Coalition Management. Cambridge: Cambridge University Press.

Key, V. O., Jr. 1949. Southern Politics in State and Nation. New York: Alfred A. Knopf. Levendusky, Matthew. 2009. The Partisan Sort: How Liberals became Democrats and Conservatives became Republicans. Chicago: University of Chicago Press. 
Mayhew, David R. 1974. Congress: The Electoral Connection. New Haven: Yale University Press.

McKee, Seth C. 2008. "Redistricting and Familiarity with U.S. House Candidates." American Politics Research 36(6): 962-979.

McKee, Seth C. 2010. Republican Ascendancy in Southern U.S. House Elections. Boulder, CO: Westview Press.

McKee, Seth C., and Daron R. Shaw. 2005. "Redistricting in Texas: Institutionalizing Republican Ascendancy," in Redistricting in the New Millennium, ed. Peter F. Galderisi. Lanham, MD: Lexington Books.

McKee, Seth C., and Antoine Yoshinaka. 2015. "Late to the Parade: Party Switchers in Contemporary US Southern Legislatures.” Party Politics 21(6): 957-969.

Meredith, Marc. 2013. "Exploiting Friends-and-Neighbors to Estimate Coattail Effects." American Political Science Review 107(4): 743-765.

Nicholson, Stephen P. 2005. "The Jeffords Switch and Public Support for Divided Government." British Journal of Political Science 35(2): 343-356.

Reiter, Howard L., and Jeffrey M. Stonecash. 2011. Counter Realignment: Political Change in the Northeastern United States. Cambridge: Cambridge University Press.

Rohde, David W. 1991. Parties and Leaders in the Postreform House. Chicago: University of Chicago Press.

Rosenstone, Steven J., and John Mark Hansen. 1993. Mobilization, Participation, and Democracy in America. New York: Macmillan.

Yoshinaka, Antoine. 2005. "House Party Switchers and Committee Assignments: Who Gets 'What. When, How?'” Legislative Studies Quarterly 30(3): 391-406.

Yoshinaka, Antoine. 2016. Crossing the Aisle: Party Switching by US Legislators in the Postwar Era. New York: Cambridge University Press. 